\title{
Content Based Image Retrieval (CBIR) Menggunakan Jarak dan Divergensi
}

\author{
Muliaty Yantahin \\ Program Studi Teknik Elektro Universitas Negeri Makassar \\ Jln. Malengkeri Raya Parang tambung 90221 \\ Dkifioc.yantahin@unm.ac.id
}

\begin{abstract}
Abstrak
Temu kembali citra atau yang disebut dengan Content Based Image Retrieval (CBIR), yang menggunakan Jarak dan Divergensi dimana citra yang kurang jelas gambarnya dapat ditemukan kembali dengan menggunakan Jarak dan Divergensi, dengan menggunakan pendekatan jarak dimana untuk dapat menentukan kesamaan dan ketidaksamaan citra semakin dekat jarak semakin besar akan ditemukannya citra, Divergensi dapat dilakukan dengan citra yang sering muncul atau nilai probabilitasnya tinggi dalam satu citra, metode CBIR yang digunakan untuk mengeksploitasi informasi pengguna mengenai relevansi dalam mengambil citra, CBIR dapat ditingkatkan secara signifikan dengan menggunakan metode Jarak dan Divergensi. sejumlah objek telah disimpan di dalam database. Selanjutnya, ketika suatu citra dijadikan sebagai bahan query, fitur akan dihitung setelah melalui prapemrosesan dan segmentasi. Fitur yang diperoleh dibandingkan dengan fitur semua objek yang terdapat di dalam database, melalui perhitungan jarak fitur. Hasil jarak ini sering disebut sebagai skor atau ranking. Seluruh skor diurutkan dari yang paling bernilai kecil ke yang paling besar. Objek-objek yang menghasilkan skor rendah adalah citra yang mirip dengan citra query. Untuk membatasi, hanya $n$ citra yang disajikan sebagai hasil query. Dalam hal ini, nilai $n$ dapat ditentukan oleh sistem ataupun pengguna.
\end{abstract}

Kata Kunci : Citra, Jarak dan Divergensi, CBIR

\begin{abstract}
Image retrieval or what is called Content Based Image Retrieval (CBIR), which uses Distance and Divergence where unclear images can be rediscovered using Distance and Divergence, using a distance approach where to be able to determine the similarity and inequality of images getting closer to distance the greater the image will be found, the Divergence can be done with images that often appear or high probability values in one image, the CBIR method used to exploit user information regarding the relevance of taking images, CBIR can be significantly increased by using the Distance and Divergence method. a number of objects have been stored in the database. Furthermore, when an image is used as a query material, the features will be counted after going through preprocessing and segmentation. The features obtained are compared with the features of all objects contained in the database, by calculating the feature distance. The result of this distance is often referred to as a score or ranking. All scores are sorted from least to greatest. The objects that generate low scores are images that are similar to the query image. To limit, only $n$ images are presented as query results. In this case, the value of $n$ can be determined by the system or the user.
\end{abstract}

Keywords: Image, Distance and Divergence, CBIR

\section{PENDAHULUAN}

Temu kembali citra (image retrieval) meruapakan proses untuk mendapatkan sejumlah citra berdasarkan masukan satu citra[1]. Istilah yang lebih spesifik adalah Content Based Image Retrieval (CBIR) atau temu kembali citra berdasarkan isinya. Awalnya CBIR digunakan untuk pencarian citra secara otomatis di dalam suatu database didasarkan pada fitur warna dan bentuk. Sejak saat itu[2], bermunculan berbagai sistem CBIR. Contoh yang terkenal adalah Query By Image Content (QBIC) yang dikembangkan oleh IBM[3]. Pada perkembangan selanjutnya, fitur tekstur juga dimasukkan sebagai bagian untuk melakukan pencarian citra. Fitur sejumlah objek telah disimpan di dalam database[4]. Selanjutnya, ketika suatu citra dijadikan sebagai bahan query, fitur akan dihitung setelah melalui prapemrosesan dan segmentasi[5]. Fitur yang diperoleh dibandingkan dengan fitur semua objek yang terdapat di dalam database, melalui perhitungan jarak fitur. Hasil jarak ini sering disebut sebagai skor atau 
ranking[6]. Seluruh skor diurutkan dari yang paling bernilai kecil ke yang paling besar. Objek-objek yang menghasilkan skor rendah adalah citra yang mirip dengan citra query. Untuk membatasi, hanya $\mathrm{n}$ citra yang disajikan sebagai hasil query. Dalam hal ini, nilai $n$ dapat ditentukan oleh sistem ataupun pengguna.

Sebenarnya, tujuan utama dari penelitian ini adalah untuk mengklarifikasi jika pendekatan CBIR yang tersedia (dikembangkan oleh kami) sesuai untuk pengakuan objek dinamis dalam klip video. Tujuan ini menentukan formulasi use case - pengakuan alfabet bahasa isyarat "statis". Kasus penggunaan lain, misalnya pengenalan wajah dalam bingkai, akan membutuhkan sumber daya data yang jauh lebih besar untuk percobaan, misalnya $\sim 28$ kali lebih besar. Artinya, untuk akumulasi IDB dengan jumlah sampel yang sama, kita akan membutuhkan wajah unik 28 orang, versus satu penandatangan yang menunjukkan 28 tanda alfabet SL.

Kecuali jika pengguna secara eksplisit menandai wilayah yang diminati atau wilayah yang diminati berada di lokasi yang tetap, CBIR yang terlokalisasi harus bergantung pada beberapa gambar berlabel untuk mempelajari bagian gambar mana yang menarik bagi pengguna. Kami mendefinisikan set gambar permintaan sebagai satu set gambar yang diberi label oleh pengguna sebagai positif atau negatif tergantung pada apakah mereka mengandung konten yang diinginkan atau tidak. Kumpulan gambar kueri dapat langsung disediakan oleh pengguna atau dapat diperoleh dengan menggunakan umpan balik relevansi dengan menambahkan gambar umpan balik berlabel ke gambar kueri asli (diberi label sebagai positif). Sementara banyak sistem CBIR klasik menggunakan umpan balik relevansi untuk menyempurnakan pencarian, sebagian besar sistem tersebut menggunakan ukuran kesamaan global yang ditimbang ulang berdasarkan gambar umpan balik. Dalam CBIR yang dilokalkan, kumpulan gambar permintaan harus digunakan untuk mengidentifikasi bagian dari gambar yang relevan dengan pencarian pengguna, juga untuk menentukan bobot fitur yang sesuai. Selain itu, bagian yang relevan dari gambar sering merupakan objek yang dapat bervariasi dalam ukuran, orientasi, dan lokasi. Dalam makalah ini kami menyajikan sistem CBIR menggunakan gambar permintaan kecil yang ditetapkan bersama dengan algoritma pembelajaran multi-instance untuk mengidentifikasi konten lokal yang diinginkan, menimbang kembali fitur, dan kemudian memberi peringkat gambar dalam repositori gambar dengan konten mereka.

\section{TINJAUAN PUSTAKA}

Istilah tersebut dikemukakan pertama kali oleh Kato pada tahun 1992. Terlepas dari meningkatnya minat ini, sebagian besar sistem pengambilan gambar berbasis konten (CBIR) yang diusulkan dalam literatur membahas gambar raster (untuk diskusi umum tentang sistem CBIR [7], Di sisi lain, ada kebutuhan yang diakui untuk mencari basis data vektor-gambar tidak hanya berdasarkan kata kunci atau penjelasan teks, tetapi juga berdasarkan pada fitur visual (seperti bentuk, warna, dan tekstur). Pekerjaan kami berasal dari persyaratan lingkungan produksi animasi 2D (aplikasi tipikal yang mengandalkan gambar vektor), di mana pencarian yang efisien terhadap materi animasi sangat penting untuk membantu kartunis dalam menggunakan kembali adegan[8]. Sistem CBIR yang mendukung karya kartunis karenanya harus terdiri dari pengambilan fitur primitif (seperti bentuk), dan pengambilan oleh fitur logis, ditujukan untuk mengekstraksi gambar dari kategori tertentu[9]. Domain aplikasi lain yang menggunakan gambar vektor (misalnya, Clip-art, menggambar, dan sistem CAD) berbagi persyaratan pengambilan yang serupa. Ini mengarah pada masalah seperti mengurangi uang penyimpanan dan menanyakan database, mendapatkan informasi yang anda butuhkan dari database secara akurat dan secepat mungkin[10]. Sebagai konsekuensi dari ukuran database gambar, penelitian tentang pengambilan gambar berbasis konten telah menerima banyak perhatian baru-baru ini. Menurut cakupan representasi, fitur ini terdiri dari dua jenis fitur global dan fitur local[11]. Kategori pertama meliputi histogram tekstur, histogram warna, tata letak dan fitur warna yang dipilih oleh diskriminasi multidimensi, analisis koleksi gambar sedangkan warna, tekstur dan bentuk dalam kategori lain. Pengambilan berbasis konten menyiratkan penggunaan fitur visual tingkat rendah seperti bentuk warna dan tekstur untuk pencarian dan pengambilan gambar.

Pendekatan kedua cukup sederhana dari sudut pandang seorang fotografer. Namun, ini membutuhkan ketelitian tinggi dan tingkat keterampilan "akting" pada bagian "pemberi tanda benda", ketika melakukan gerakan seragam di depan kamera. Jika penandatangan tidak cukup terlatih untuk peran yang dipermasalahkan, akan diperlukan upaya tambahan untuk "menormalkan" film. Dengan kata lain, pendekatan ini tidak dapat diterima untuk tujuan kami, bahkan jika itu cukup populer dari praktik pengumpulan data yang serupa,

Pendekatan ketiga, dibandingkan dengan dua yang pertama, tidak secara langsung berorientasi pada pembuatan klip video. Yang terakhir perlu komputer yang dihasilkan dari beberapa foto statis, diambil dari posisi yang berbeda dalam sektor spasial yang diperlukan di sekitar / di depan objek. 
Pendekatan ini nyaman dari sudut pandang penandatangan, tetapi tidak dapat diterima untuk tujuan kami. Upaya pengembangan yang diperlukan untuk menghasilkan film atau urutan bingkai akhir (meniru posisi paparan yang cukup dekat) terlalu mahal

\section{RESEARCH METHODE DAN PEMBAHASAN}

Jarak dan divergensi merupakan pendekatan yang umum dipakai untuk mewujudkan pencarian citra sehingga lebih mempermudah dalam mendeteksi citra yang akan ditemukan kembali. Fungsinya adalah untuk menentukan kesamaan atau ketidaksamaan dua vektor fitur. Tingkat kesamaan dinyatakan dengan suatu skor atau ranking. Semakin kecil nilai ranking, semakin dekat kesamaan kedua vektor tersebut untuk ditemukan kembali, sebaliknya bila semakin besar nilai ranking, semakin jauh dari kesamaan kedua vektor maka semakin sulit ditemukan citra tersebut.

Sistem ini menggunakan konten visual seperti warna, gradien, tekstur, dan bentuk untuk mencari gambar dari basis data gambar skala besar. Salah satu alasan utama keberhasilan CBIR yang terbatas adalah bahwa metode-metode ini bergantung pada pandangan global (holistik) dari gambar. Solusi untuk masalah ini dapat diatasi dengan menggunakan objek-centric CBIR. Klasik Pengambilan Gambar Berbasis Konten ( CBIR) mengambil satu gambar permintaan tanpa anotasi, dan mengambil gambar yang serupa dari gudang gambar. Pencarian seperti itu harus bergantung pada pandangan holistik (atau global) dari gambar. Namun seringkali konten yang diinginkan dari suatu gambar tidak holistik, tetapi dilokalkan. Secara khusus, kami mendefinisikan Pengambilan Gambar Berbasis Konten Lokal sebagai tugas CBIR di mana pengguna hanya tertarik pada bagian gambar, dan sisanya gambar tidak relevan. Banyak sistem CBIR klasik menggunakan umpan balik relevansi untuk mendapatkan gambar yang berlabel diinginkan atau tidak diinginkan. Namun, gambar berlabel ini biasanya hanya digunakan untuk menimbang ulang fitur yang digunakan dalam ukuran kesamaan global. Seperti yang diperlihatkan pada gambar berikut ini.

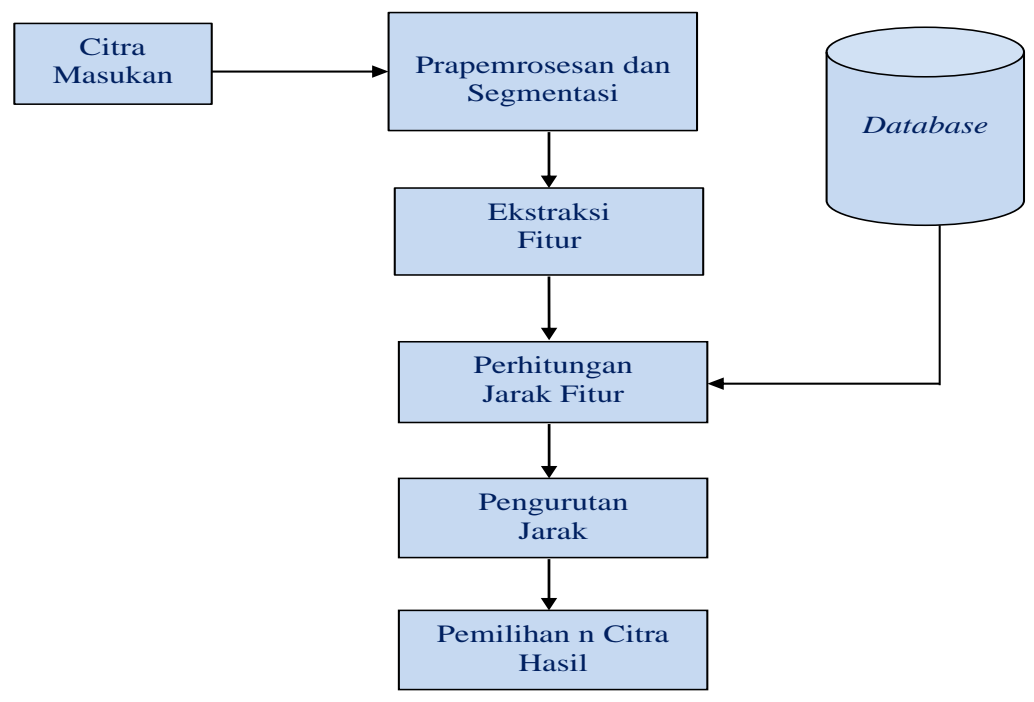

Gambar 1 Alur Temu Kembali Citra

\subsection{Perhitungan Citra Antara Dua Citra}

Jarak merupakan pendekatan yang umum dipakai untuk mewujudkan pencarian citra. Fungsinya adalah untuk menentukan kesamaan atau ketidaksamaan dua vektor fitur. Tingkat kesamaan dinyatakan dengan suatu skor atau ranking. Semakin kecil nilai ranking, semakin dekat kesamaan kedua vektor tersebut.

Query = im2bw(imread(berkas), 0.5);

ZQuery = zermoment $($ Query, 10);

Hasil $=[]$; 


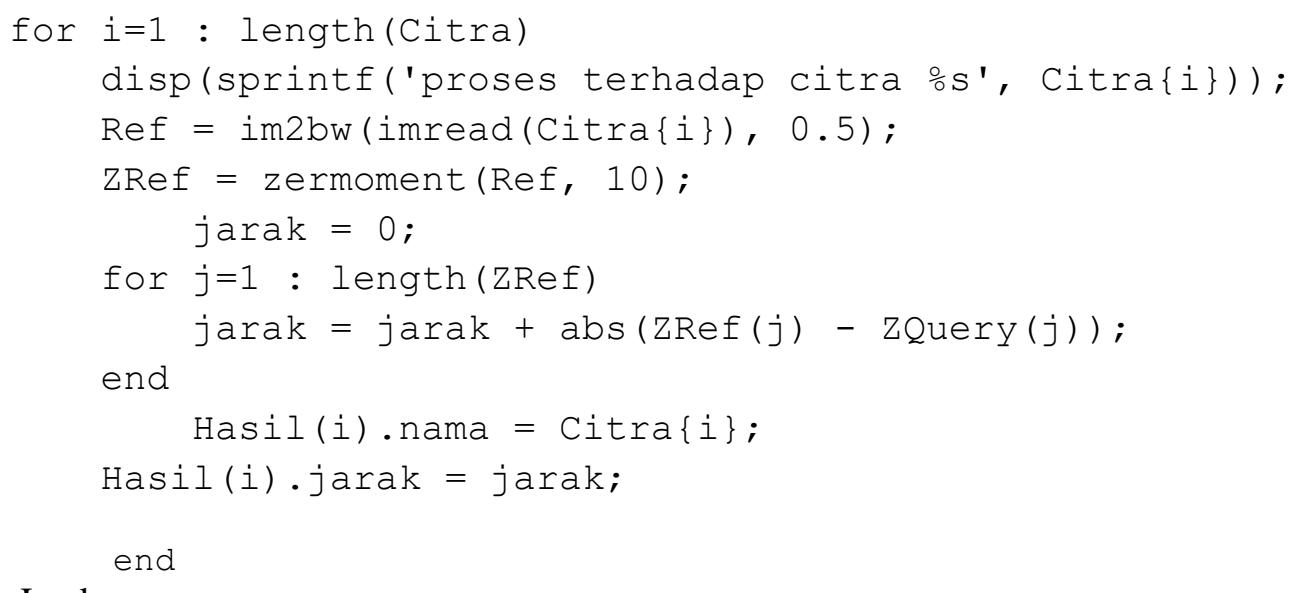

3.1 Jarak

Jarak Euclidean didefinisikan sebagai berikut:

$$
j\left(v_{1}, v_{2}\right)=\sqrt{\sum_{k=1}^{N}\left(v_{1}(k)-v_{2}(k)\right)^{2}}
$$

Dalam hal ini, $v 1$ dan $v_{2}$ adalah dua vektor yang jaraknya akan dihitung dan $\mathrm{N}$ menyatakan panjang vektor. Apabila vektor memiliki dua nilai, jarak Euclidean dapat dibayangkan sebagai sisi miring segitiga (Gambar 2).

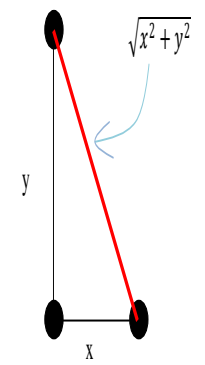

(a) jarak Euclidean

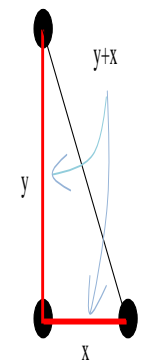

(b) Jarak city-block

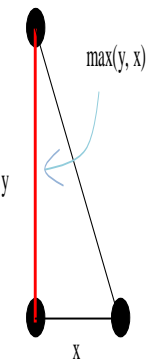

(c) Jarak Chebychef

\section{Gambar 2 Gambaran jarak}

Sebagai contoh, terdapat dua vektor

$$
\text { seperti berikut: }
$$

$$
\begin{aligned}
& v_{1}=[4,3,6] \\
& v_{2}=[2,3,7]
\end{aligned}
$$

Jarak Euclidean kedua vektor

adalah:

$$
\text { jarak }=\sqrt{(4-2)^{2}+(3-3)^{2}+(6-7)^{2}}=\sqrt{5}=2,2361
$$

Jarak Euclidean merupakan jarak yang umum dipakai dalam temu kembali citra. Beberapa penelitian yang memanfaatkan jarak ini antara lain dilakukan.

Jarak city-block didefinisikan sebagai berikut:

$$
j\left(v_{1}, v_{2}\right)=\sum_{k=1}^{N}\left|v_{1}(k)-v_{2}(k)\right|
$$

Dalam hal ini, $v_{l}$ dan $v_{2}$ adalah dua vektor yang jaraknya akan dihitung dan $\mathrm{N}$ menyatakan panjang vektor. Apabila vektor memiliki dua nilai, jarak city-block dapat dibayangkan sebagai jarak vertikal plus horizontal dari vektor pertama ke vektor kedua (Gambar 2). Sebagai contoh, terdapat dua vektor seperti berikut:

$$
v_{1}=[4,3,6]
$$




$$
v_{2}=[2,3,7]
$$

Jarak city-block kedua vektor tersebut berupa

$$
\text { jarak }=|4-2|+|3-3|+|6-7|=3
$$

Jarak kotak catur atau dikenal pula dengan nama jarak Chebychef didefinisikan sebagai berikut:

$$
j\left(v_{1}, v_{2}\right)=\max _{k=1 \rightarrow N}\left(\left|v_{1}(k)-v_{2}(k)\right|\right)
$$

Dalam hal ini, $v_{I}$ dan $v_{2}$ adalah dua vektor yang jaraknya akan dihitung dan $\mathrm{N}$ menyatakan panjang vektor. Apabila vektor memiliki dua nilai, jarak dapat dibayangkan sebagai jarak terpanjang antara jarak horizontal dan jarak vertikal (Gambar 14.2(c)). Sebagai contoh, dengan dua vektor yang sama dengan di depan $\left(v_{1}=[4,3,6]\right.$ dan $\left.v_{2}=[2,3,7]\right)$, jarak kotak catur kedua vektor tersebut berupa jarak $=\max (|4-2|,|3-3|,|6-7|)=2$

Jarak Minkowski didefinisikan sebagai berikut:

$$
j\left(v_{1}, v_{2}\right)=\sqrt[1 / p]{\sum_{k=1}^{N} \mid\left(v_{1}(k)-\left.v_{2}(k)\right|^{p}\right.}
$$

Dalam hal ini, $v_{l}$ dan $v_{2}$ adalah dua vektor yang jaraknya akan dihitung dan $\mathrm{N}$ menyatakan panjang vektor. Apabila p bernilai 1, jarak berupa city-block. Apabila p bernilai 2, jarak berupa Euclidean. Sebagai contoh, dengan dua vektor yang sama dengan di depan $\left(v_{1}=[4,3,6]\right.$ dan $\left.v_{2}=[2,3,7]\right)$, jarak Minkowski kedua vektor tersebut untuk p berupa 3 berupa:

$$
\text { jarak }=\sqrt[1 / 3]{(4-2)^{3}+(3-3)^{3}+(6-7)^{3}}=\sqrt[1 / 3]{9}=2,0801
$$

Jarak Canberra didefinisikan $\quad$ sebagai berikut:

$$
j\left(v_{1}, v_{2}\right)=\sum_{k=1}^{N} \frac{\left|v_{1}(k)-v_{2}(k)\right|}{\left|v_{1}(k)\right|+\left|v_{1}(k)\right|}
$$

Dalam hal ini, $v_{l}$ dan $v_{2}$ adalah dua vektor yang jaraknya akan dihitung dan $\mathrm{N}$ menyatakan panjang vektor.

Sebagai contoh, dengan dua vektor yang sama dengan di depan $\left(v_{1}=[4,3,6]\right.$ dan $\left.v_{2}=[2,3,7]\right)$, jarak Canberra kedua vektor tersebut berupa

$$
\text { jarak }=\frac{|4-2|}{4+2}+\frac{|3-3|}{3+3}+\frac{|6-7|}{6+7}=\frac{2}{6}+\frac{0}{6}+\frac{1}{13}=0,4103
$$

Jarak Bray Curtis atau jarak Sorensen (Putra, 2010) didefinisikan sebagai berikut:

$$
j\left(v_{1}, v_{2}\right)=\frac{\sum_{k=1}^{N}\left|v_{1}(k)-v_{2}(k)\right|}{\sum_{k=1}^{N} v_{1}(k)+\sum_{k=1}^{N} v_{2}(k)}
$$

Dalam hal ini, $v_{l}$ dan $v_{2}$ adalah dua vektor yang jaraknya akan dihitung dan $\mathrm{N}$ menyatakan panjang vektor.

Sebagai contoh, dengan dua vektor yang sama dengan di depan $\left(v_{1}=[4,3,6]\right.$ dan $\left.v_{2}=[2,3,7]\right)$, jarak Bray Curtis kedua vektor tersebut berupa

$$
\text { jarak }=\frac{|4-2|+|3-3|+|6-7|}{4+2+3+3+6+7}=\frac{2+1}{25}=0,12
$$




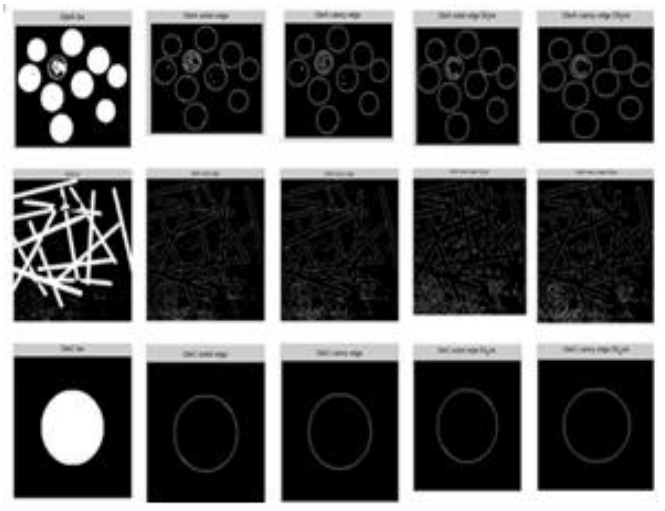

Gambar CBIR Image

\subsection{Divergensi}

Divergensi Kullback Leibler (Deselaers, 2003) didefinisikan sebagai berikut:

$$
K L\left(v_{1}, v_{2}\right)=\sum_{k=1}^{N} v_{1}(k) \log \frac{v_{1}(k)}{v_{2}(k)}
$$

Dalam hal ini, $v_{1}$ dan $v_{2}$ adalah dua vektor yang jaraknya akan dihitung dan $\mathrm{N}$ menyatakan anjang vektor.

Sebagai contoh, dengan dua vektor yang sama dengan di depan $\left(v_{1}=[4,3,6]\right.$ dan $v_{2}=$ $[2,3,7])$, jarak menurut divergensi Kullback Leibler kedua vektor tersebut berupa

jarak $=4 * \log \left(\frac{4}{2}\right)+3 * \log \left(\frac{3}{3}\right)+6 * \log \left(\frac{6}{7}\right)=1,8477$

Divergensi Jensen Shannon (Deselaers, 2003) didefinisikan sebagai berikut:

$J D\left(v_{1}, v_{2}\right)=\sum_{k=1}^{N} v_{1}(k) \cdot \log \frac{2 * v_{1}(k)}{v_{1}(k)+v_{2}(k)}+v_{2}(k) \cdot \log \frac{2 * v_{2}(k)}{v_{1}(k)+v_{2}(k)}$

Dalam hal ini, $v_{l}$ dan $v_{2}$ adalah dua vektor yang jaraknya akan dihitung

dan

$\mathrm{N}$ menyatakan panjang vektor.

Sebagai contoh, dengan dua vektor yang sama dengan di depan $\left(v_{1}=[4,3,6]\right.$ dan $v_{2}=$ $[2,3,7])$, jarak menurut divergensi Jensen Shannon kedua vektor tersebut berupa

$$
\begin{aligned}
\text { jarak }= & 4 * \log \left(\frac{2 * 4}{4+2}\right)+3 * \log \left(\frac{2 * 3}{3+3}\right)+6 * \log \left(\frac{2 * 6}{6+7}\right)+ \\
& 2 * \log \left(\frac{2 * 2}{4+2}\right)+3 * \log \left(\frac{2 * 3}{3+3}\right)+7 * \log \left(\frac{2 * 7}{6+7}\right)=0,3783
\end{aligned}
$$

\section{KESIMPULAN}

CBIR atau kembali citra dpat dilakukan denganjarak dan divergensi yang sesuai dengan aturan-aturan yang telah disepakati terlebih dahulu, dimana citra yang akan di temukan haruslah memilki jarak dan divergensi. Sebagai konsekuensi dari ukuran database gambar, penelitian tentang pengambilan gambar berbasis konten telah menerima banyak perhatian baru-baru ini. Menurut cakupan representasi, fitur ini terdiri dari dua jenis fitur global dan fitur lokal. Kategori pertama meliputi histogram tekstur, histogram warna, tata letak dan fitur warna yang dipilih oleh diskriminasi multidimensi, analisis koleksi gambar sedangkan warna, tekstur dan bentuk dalam kategori citra yang lain. Mengambil gambar dari koleksi besar dan beragam menggunakan konten gambar (seperti warna, bentuk, tekstur) sebagai kuncinya adalah masalah yang menantang dan penting. Makalah ini menjelaskan pendekatan baru \& efektif untuk Pengambilan Gambar Berbasis Konten (CBIR) yang mewakili setiap gambar dalam basis data oleh vektor nilai fitur yang disebut "Transformasi Wavelet pada Distribusi Pixel Baris dan Kolom BMP untuk CBIR". Di sini kami mengusulkan pendekatan sederhana dan efektif yang dapat dengan mudah diimplementasikan dalam bahasa pemrograman. Dalam teknik ini deviasi standar dan rata-rata koefisien wavelet dari distribusi warna baris dan kolom digunakan sebagai vektor fitur gambar. Kami menggunakan 
harr wavelet untuk tujuan ini. Kami mendapatkan vektor fitur ringkas yang membuat tanda tangan gambar dalam hal kedua tekstur dan warna. Kami menggunakan jarak Euclidean sederhana untuk menghitung ukuran kesamaan gambar untuk aplikasi Pengambilan Gambar Berbasis Konten. Teknik ini memberikan hasil yang dapat diterima dengan cara yang sederhana dan cepat.

\section{DAFTAR PUSTAKA}

[1] N. Gupta, "Revealing What to Extract from Where, for Object-Centric Content Based Image Retrieval ( CBIR )."

[2] D. Dimov, A. Marinov, and N. Zlateva, "CBIR Approach to the Recognition of a Sign Language Alphabet (*)," pp. 1-9, 2007.

[3] T. Di Mascio, I. Elettrica, and I.-M. Roio, "Tuning a CBIR system for vector images : the interface support," pp. 425-428, 2004.

[4] B. A. Bobier and M. Wirth, "Content-Based Image Retrieval Using Hierarchical Temporal Memory," pp. 925-928, 2008.

[5] J. Chen, "Weighting Visual Features with Pseudo Relevance Feedback for CBIR," pp. 220-227.

[6] G. F. Ahmed, “CBIR Using Fuzzy Edge Detection Mask," pp. 277-280, 2011.

[7] J. Wang, "Content-based Image Retrieval Based On Eye-tracking," 2016.

[8] H. Zhang, R. Rahmani, S. R. Cholleti, and S. A. Goldman, "Local Image Representations Using Pruned Salient Points with Applications to CBIR," pp. 287-296, 2006.

[9] X. S. Zhou, S. Zillner, M. Moeller, and M. Sintek, "Semantics and CBIR: A Medical Imaging Perspective Categories and Subject Descriptors," pp. 571-580, 2008.

[10] E. L. Van Den Broek, P. M. F. Kisters, and L. G. Vuurpijl, "Design Guidelines for a Content-Based Image Retrieval Color-Selection Interface," pp. 1-4.

[11] M. Taileb, "Content Based Image Retrieval System Using NOHIS-tree," pp. 103-108, 2012. 